\title{
Non-TrkA-Expressing Small DRG Neurons Are Lost in TrkA Deficient Mice
}

\author{
Inmaculada Silos-Santiago, ${ }^{1, a}$ Derek C. Molliver, ${ }^{1}$ Shigeru Ozaki, ${ }^{1}$ Richard J. Smeyne, ${ }^{2}$ Anne M. Fagan, ${ }^{2}$ \\ Mariano Barbacid, ${ }^{2}$ and William D. Snider ${ }^{1}$ \\ ${ }^{1}$ Center for the Study of Nervous System Injury, Department of Neurology, Washington University School of \\ Medicine, St. Louis, Missouri 63110 and ${ }^{2}$ Department of Molecular Biology, Bristol-Myers Squibb, Princeton, New \\ Jersey 08543-4000
}

\begin{abstract}
Experiments over the past decade in which NGF/TrkA signaling has been abolished by antibodies or targeted gene mutations have shown that $70-85 \%$ of dorsal root ganglion (DRG) neurons require NGF for survival during development. There is consensus that many of the NGF-dependent neurons are small-diameter, peptidergic neurons subserving nociception. These neurons express the signaling receptor for NGF, TrkA. There is a major discrepancy, however, between the percentage of DRG neurons which require NGF for survival (70-85\%) and percentage of DRG neurons expressing TrkA receptors (40-50\%). The identity of these non-TrkA expressing, NGF-dependent neurons has not been established. A candidate group is a population of small DRG neurons with unmyelinated axons which bInd BSI Isolectins from the plant, Bandeiraea simplicifolia. We show here that most of these BSI-binding DRG neurons do not express TrkA in adult mice. However, in mutant mice in which NGF/TrkA signaling has been abolished by inactivation of the trkA gene, BSI-staining in the DRG and dorsal horn is completely eliminated. BSI-binding DRG cells are thus the first identified neuronal population in which cells do not express TrkA in maturity, but require NGF/TrkA signaling for survival during embryonic development. These neurons must either depend on NGF via a novel, indirect mechanism or alternatively, downregulate TrkA expression during development.
\end{abstract}

[Key words: TrkA, NGF, DRG neurons, dorsal horn, cell death, neurotrophin receptors]

The neurotrophins are a family of neuronal growth factors which act via specific receptor tyrosine kinases to regulate the development and differentiated properties of many classes of neurons in the PNS and CNS (for reviews, see Eide et al., 1993; Korsching, 1993; Snider, 1994). Although gene localization and phar-

Received Mar. 10, 1995; revised May 8, 1995; accepted May 18, 1995.

We thank Dr. Louis F. Reichardt for the generous gift of the antibody RtkEx. We thank Dr. R. E. Smith, S. Plurab, and L.N. Beaudet for expert assistance with electron microscopy. We are grateful to Drs. J. Elliott, F. White, and D Wright for helpful discussions and a critical reading of the manuscript. This work was supported in part by R01 NS31768 and Program Project NS17763 from the NINDS.

Correspondence should be addressed to W. D. Snider, M.D., Center for the Study of Nervous System Injury. Department of Neurology, Box 8111, Washington University School of Medicine, 660 South Euclid Avenue, St. Louis, MO 63110.

Present address: Department of Molecular Biology, Bristol-Myers Squibb, Princeton, NJ 08543-4000.

Copyright 1995 Society for Neuroscience $0270-6474 / 95 / 155929-14 \$ 05.00 / 0$ macological studics have suggested biological actions for these molecules, many aspects of their functions in vivo remain unresolved. The recent generation of mice in which neurotrophins or their receptor genes (trks) have been deleted by homologous recombination have provided definitive tools with which to delineate functions of neurotrophins during development. Studies in these animals have revealed that neurotrophin/Trk signaling is required for the survival of most classes of primary sensory neurons in the PNS (Klein et al., 1993; Crowley et al., 1994; Ernfors et al., 1994a,b; Fariñas et al., 1994; Jones et al., 1994; Klein et al., 1994; Smeyne et al., 1994). A particularly clear understanding of neurotrophin actions is emerging for neurons of the dorsal root ganglion (DRG). It has become apparent that neurotrophin dependence of these neurons is strikingly segregated according to sensory modality. Thus, DRG neurons mediating nociception require the prototypical neurotrophin, NGF and express its signaling receptor, TrkA (Johnson et al., 1980; Carroll et al., 1992; Ruit et al., 1992; Crowley et al., 1994; Smeyne et al., 1994), while neurons mediating proprioception require the more recently identified neurotrophin-3 (NT-3) and express its primary signaling receptor, TrkC (Ernfors et al., 1994b; Fariñas et al., 1994; Klein et al., 1994). The classes of DRG neurons which are dependent on brain-derived neurotrophic factor (BDNF) or neurotrophin-4/5 (NT-4/5) and express their common signaling receptor, TrkB, have not yet been identified (see Klein et al., 1993; Silos-Santiago et al., 1993; Ernfors et al., 1994a; Jones et al., 1994).

The idea that NGF regulates the development of nociceptors is derived from studies which show that animals deprived of NGF/TrkA-signaling during embryonic life have reduced sensitivity to painful stimuli (Johnson et al., 1980; Crowley et al., 1994; Smeyne et al., 1994), that their DRGs are depleted of small-diameter neurons (Johnson et al., 1980; Ruit et al., 1992; Crowley et al., 1994; Smeyne et al., 1994), and that their DRGs show reduced levels of calcitonin gene-related peptide (CGRP) and substance P (SP) (Kessler and Black, 1980; Otten et al., 1980; Crowley et al., 1994), peptides associated with nociceptive functions (see Lawson, 1992, for a review). Furthermore, the DRG neurons that are lost project to superficial laminae in the dorsal horn, the area of the spinal cord associated with primary nociceptive processing (Ruit et al., 1992). Although the idea that NGF regulates nociceptors is established in a general sense, it is important to emphasize that nociceptive neurons are very heterogeneous in their functional and morphological properties (see Perl, 1992; Lewin and Mendell, 1993, for reviews). Thus, DRG 
neurons physiologically classified as nociceptors differ on the basis of myelinated or unmyelinated axons, projections to different laminae of the dorsal horn, peptide expression, expression of different classes of intermediate filaments, differential binding of lectins, and synthesis of cytoplasmic enzymes (see Lawson, 1992, for a review). Whether all, or only some, of these various subpopulations of nociceptive DRG neurons are regulated by NGF/TrkA signaling has not yet been clarified.

Another unresolved issue about the NGF dependence of DRG neurons is the discrepancy between the percentage of DRG neurons lost in the setting of NGF deprivation and the percentage of DRG neurons which express the signaling NGF receptor, TrkA. Indeed, in situ hybridization and immunohistochemical studies have reported that TrkA-expressing neurons represent only $40-50 \%$ of the total ncuronal population in the mature rat DRG (Verge et al., 1992; Ernfors et al., 1993; Averill et al., 1994; Molliver et al., 1995; see also Verge et al., 1989; Mu et al., 1993a), while reported neuronal loss after abolishing NGF/ TrkA signaling during development has varied between 70 and $85 \%$ in both rats and mice (Johnson et al., 1980; Ruit et al., 1992; Crowley et al., 1994; Smeyne et al., 1994). A group of DRG neurons of particular interest in light of this discrepancy is a small-diameter population which bind BSI isolectins of the plant, Bandeiraea simplicifolia. These lectin-binding neurons account for roughly $30-40 \%$ of the rat DRG population (see Hunt et al., 1992). Although data are conflicting on this point, it appears that most of these neurons do not express substance $P$ or CGRP (see Hunt et al., 1992; Lawson, 1992, for reviews). Furthermore, this population is probably identical to a group of small diameter DRG neurons which do not bind NGF with high affinity in adult animals (Verge et al., 1989), or show TrkAimmunoreactivity (Molliver et al., 1995). Whether these lectinbinding DRG neurons require NGF for survival during development is unknown.

Here, we have used mice in which the NGF receptor, TrkA, has been inactivated by gene targeting in order to define further populations of primary sensory neurons which require NGF/ TrkA signaling for survival. We show that all neurons that have been associated with nociceptive functions on the basis of axon caliber, dorsal horn projections, intermediate filament content, and peptide staining are lost in the homozygous trkA mutant mice. We also show that a large proportion of DRG neurons that bind BSI do not express TrkA in postnatal life, and therefore should be NGF-independent. Surprisingly, the BSI-positive neurons are also lost in trkA $(-/-)$ mutant mice. These lectinbinding DRG neurons must either require interactions with Trk $\Lambda$ expressing neurons for their survival, or downregulate TrkA during embryonic development.

\section{Materials and Methods}

Generation of trkA $(-1-)$ mutant mice. Mice heterozygous for a targeted mutation in the tyrosine kinase domain of the trkA locus were generated as described in Smeyne et al. (1994).

Anesthesia and perfusion. Pregnant mice and 2 week postnatal pups were anesthetized by intraperitoneal injection of a 3:3:1 cocktail of $x y-$ lazine $(10 \mathrm{mg} / \mathrm{kg})$, ketamine $(95 \mathrm{mg} / \mathrm{kg})$, and acepromazine maleate $(0.7$ $\mathrm{mg} / \mathrm{kg}$ ). Embryonic day 17 fetuses were anesthetized by hypothcrmia. Animals were perfused transcardially with $4 \%$ paraformaldehyde in 0.1 $\mathrm{M}$ phosphate buffer ( $\mathrm{pH}$ 7.2). All animals were postfixed in fresh fixative for at least $24 \mathrm{hr}$. Animals were processed separately for immunohistochemistry.

Tissue preparation for cell counting, morphometric, and ultrastructural studies. Following fixation, spinal cords were removed with dorsal root ganglia attached. L4 and L5 ganglia were embedded in paraffin before being transversely sectioned on a microtome at $8 \mu \mathrm{m}$ for the DRG cell counts. Contralateral DRGs and dorsal roots were dissected, osmicated, dehydrated through a graded ethanol series, and embedded in Spurr resin (Electron Microscopy Sciences, FT. Washington, PA). Transverse semithin sections $(1 \mu \mathrm{m})$ were cut and stained with toluidine blue. Ultrathin sections were cut at $60 \AA$ and stained with uranyl acetate and lead citrate. Ultrathin sections were visualized with a JOEI $1200 \mathrm{~F}$.X transmission electron microscope, and photographed using Kodak 4489 electron image film.

DRG neuronal counts. Paraffin sections were stained with $1 \%$ cresyl violet, and DRG neuron counts were made from every tenth section. The numbers of DRG neurons in L4 and L5 ganglia were determined by counting only cells with an obvious nucleus containing one or more nucleoli. DRG neurons were viewed using at $50 \times$ objective on a Nikon Microphot FXA photomicroscope. In order to correct for split nuclei, 36 fields were sampled randomly. Fields were photographed using a Kodak DCS 200 digital camera, and images downloaded to a Macintosh Quadra 900 . Images were adjusted for brightness and contrast using ADOBE PHOTOSHOP 2.5.1. For each pair of sampled fields, both the bottom of one section and the surface of the consecutive section were photographcd. Wc counted the number of cell nuclei that appeared in both fields. We found that only $4 \%$ of the neurons with a nucleus containing nucleoli appear on two successive sections. Therefore, the final number of DRG neurons was estimated by multiplying the raw dala by the correction factor, 0.98 .

Morphometry of DRG neurons and dorsal root myelinated axons. For determination of cellular and axonal cross-sectional areas, profiles of DRG neurons and myelinated axons were traced on a digitizing tablet (Sumagraphics) interfaced with computer software designed to calculate areas (BIOQUANT, RandM Biomedics). For each genotype $((+/+)$, $(+1-)$, and $(-1-)$, size-frequency histograms were constructed for DRG neurons and dorsal root myelinated axons. Cross-sectional areas of DRG neurons or myelinated axons were compared using an unpaired Student's $t$ test. Numbers of neurons and axons measured in each group are as follows: trkA $(+/+), 609$ neurons, 651 axons; 1 rkA $(+/-), 528$ neurons, 673 axons; trkA $(-/-), 223$ neurons, 553 axons.

Antibodies. Rtk-Ex, a polyclonal antibody generated against the extracellular domain of trkA (Clary et al., 1994) was very generously provided by Dr. Louis F. Reichardt. Rtk-Ex was used at 1:8000. A monoclonal antibody to the high molecular weight neurofilament protein (NFH) (Zymed, San Francisco, CA) was used at 1:200 dilution. A rabbit polyclonal antibody generated against parvalbumin was provided by Piers Emson, and used at 1:5000. The rabbit polyclonal peripherin antibody, generously provided by Dr. Linda Parysek, was used at 1:200. The antibody to CGRP (Peninsula, Belmont, CA) was diluted to 1:750. The rabbit polyclonal SP antiserum was used at 1:500 dilution. Secondary antibodies were conjugated to CY3 (Jackson Immunochemicals, West Grove, PA ) or Bodipy (Molecular Probes, Eugene, OR) and used at 1:200.

Immunohistochemistry. Mice were perfused transcardially with $0.1 \mathrm{M}$ phosphate buffer, followed by $3 \%$ paraformaldehyde, $15 \%$ picric acid in $0.1 \mathrm{M}$ phosphate buffer, $\mathrm{pH} 7.4$. The entire vertebral column was removed and placed without postfixation into $30 \%$ sucrose for 12-24 $\mathrm{hr}$, then frozen in OCT embedding medium using liquid nitrogen. Transverse sections were cut at $12 \mu \mathrm{m}$ on a cryostat, mounted on Fisher SuperFrost/Plus slides, and allowed to air dry.

Mounted sections were encircled with a Teflon coating using a Pap pen (Kyota International, Inc., Elk Grove Village, IL), and incubated for $1 \mathrm{hr}$ in a blocking solution consisting of Superblock buffer (Pierce Chemical Company, Rockford, IL), $0.3 \%$ Triton X-100, $0.3 \%$ TWEEN 20 (Electron Microscopy Sciences, Ft. Washington, PA), 1.0\% porcine gelatin (Sigma, St. Louis, MO), and $1.5 \%$ normal serum (Vector, Burlingame, CA). This solution was diluted 1:1 with Superblock buffer/ $1.5 \%$ normal serum, and used for the dilution of primary and secondary antibodies. Sections were incubated in the primary antibody overnight (12-16 hr). Slides were then washed three times (5 min each) with PBS and incubated in the secondary antibody for $30 \mathrm{~min}$, washed again 3 $\times 5 \mathrm{~min}$ in PBS, and coverslipped in PBS or SlowFade (Molecular Probes, Eugene, OR). Sections were examined under fluorescence optics and photographed using Kodak Ektachrome color film, ASA 400.

Lectin histochemistry. Sections were processed for lectin histochemistry as above, with the following modifications. After the preincubation step, biotinylated preparations of BSI (Sigma, St. Louis, MO) were applied to tissue sections. The reagent "BSI" is a mixture of all BSI isolectins from Bandeiraea simplicifolia. In rat, this reagent binds both 
small peptidergic and small nonpeptidergic DRG neurons (Molliver et al., 1995). A particular isolectin, BSI-B4, binds primarily the nonpeptidergic population in rat (Silverman and Kruger, 1990). In our hands both BSI and BSI-B4 bind principally the nonpeptidergic population in mouse. BSI was used at a concentration of $10 \mu \mathrm{g} / \mathrm{ml}$ in PBS containing $0.01 \mathrm{M} \mathrm{MgCl}_{2}, \mathrm{CaCl}_{2}, \mathrm{pH} 6.8$, and incubated overnight. After washing in PBS, sections were incubated for $60 \mathrm{~min}$ in avidinylated Bodipy (Molecular Probes, Eugene, OR) diluted 1:200, or avidinylated CY3 (Jackson Immunochemicals, West Grove, PA) diluted 1:1000 in $50 \mathrm{~mm}$ Tris, $1.8 \%$ saline, pH 7.4, washed in Tris buffer and viewed under fluorescence. Double-labeled sections were processed completely for lectin binding, washed in blocking buffer and then processed for immunohistochemistry.

Dil labeling. Embryonic day 17 animals instead of 2 weeks postnatal pups were used for these experiments because the diffusion distance is less in embryos and because the rate of Dil diffusion is slowed in postnatal animals due to myelination. Furthermore, even at this early time $80 \%$ of DRG neurons have been already eliminated in trkA $(-1-)$ mutant mice (Silos-Santiago et al., 1994). Embryos were fixed transcardially with $4 \%$ paraformaldehyde and postfixed in the same fixative for 48 $\mathrm{hr}$, prior to Dil crystal placement. In our experience, a lighter fixation allows a somewhat faster diffusion of the tracer. Following postfixation, the viscera were removed, crystals of the carbocyanine dye $1,1^{\prime}$-dioctadecyl-3,3, $3^{\prime}, 3^{\prime}$ tetramethylindocarbocyanineperchlorate (DiI, Molecular Probes, Eugene, OR) were crushed and a small fragment placed within DRG for whole dorsal root projection labeling, or on the skin for cutaneous afferent labeling.

Following the appropriate time interval, the spinal cords were embedded in $3.5 \%$ agar and sectioned on a vibratome at $75 \mu \mathrm{m}$. Sections were then placed on microscope slides in a drop of phosphate buffer, coverslipped, and viewed on a Nikon Microphot FXA microscope under rhodamine epifluorescence. Suitable sections were photographed using Kodak Ektachrome color ASA 400 and Ilford XP1 BW ASA 400 films.

To convert Dil to a permanent label, sections were photoconverted utilizing diaminobenzidine (DAB; Sandell and Masland, 1988). Sections were placed on a slide in a solution of $2.6 \mathrm{mg} \mathrm{DAB} / \mathrm{ml}$ in $0.1 \mathrm{M}$ Tris buffer (pH 8.2) for 30-90 min. Under rhodamine epifluorescence and a $10 \times$ objective, the DAB will replace the DiI fluorescence with a permanent brown reaction product. Following photoconversion, the sections were rinsed in $0.1 \mathrm{M}$ Tris buffer $(\mathrm{pH} 8.2)$ and air-dried overnight on gel subbed slides. The sections were then stained with thionine, dehydrated in a graded series of ethanols, cleared in xylene, and coverslipped with DPX mountant (Electron Microscopy Sciences, Ft. Washington, PA).

In situ hybridization. Paraffin sections were cut at $5 \mu \mathrm{m}$ thickness and in situ hybridization was performed with ${ }^{35}$ S-labeled sense and antisense riboprobes. cRNA probes for $t r k \mathrm{C}$ and $t r k \mathrm{~B}$ were prepared as previously described (Mu et al., 1993a). Each of the $t r k$ probes recognizes the extraccllular region of the receptor.

The in situ hybridization procedures employed have been described previously (Mu et al., 1993a). Paraffin-embedded tissue sections were hybridized with radiolabeled antisense or sense probes at $55^{\circ} \mathrm{C}$ for 18 hr. Following hybridization, the sections were washed in a series of SSC washes and treated with RNaseA to digest nonhybridized, singlestranded probe. Slides were then dipped in Kodak nuclear track emulsion (NTB2, Rochester, NY) for autoradiography and stored at $4^{\circ} \mathrm{C}$. Following a 2 week exposure, slides were developed in Kodak D19, counterstained with hematoxylin and eosin (Sigma, St. Louis, MO), and mounted with DPX (Electron Microscopy Sciences, Ft. Washington, PA)

\section{Results}

Small DRG neurons are eliminated in the homozygous but not in heterozygous trkA mutants

In agreement with previous studies (Smeyne et al., 1994; see also Crowley et al., 1994), we find profound loss of primary sensory neurons in the trkA $(-/-)$ mutant mice. L4-L5 DRGs from 2 week old (P13-P15) trkA (-/-) mice have only 2195 \pm 79 neurons, compared to $12,415 \pm 1237$ neurons in the wildtype $(+/+$ ) controls (Table 1, Fig. 1). Thus, more than $80 \%$ of DRG neurons require NGF/TrkA signaling for survival during development. In contrast to this massive neuronal loss in trkA $(-/-)$ mutants, most DRG neurons in the trkA $(+/-)$ animals
Table 1. Neuronal counts in L4 and L5 dorsal root ganglia at P13-P15

\begin{tabular}{llll} 
GN & $\begin{array}{l}\text { No. cells } \\
\text { (mean } \pm \text { SEM) }\end{array}$ & $\%$ & $\begin{array}{l}\text { No. of } \\
\text { animals } \\
\text { examined }\end{array}$ \\
\hline$(+/+)$ & $12,415 \pm 1237$ & 100 & 3 \\
$(+/-)$ & $10,422 \pm 623$ & 84 & 5 \\
$(-/-)$ & $2,195 \pm 79 *$ & 18 & 5 \\
\hline
\end{tabular}

GN, Genotype.

*Differs from $(+/+), p<0.0001$.

survive. At P13-P15, trkA $(+/-)$ animals have 10,422 \pm 623 neurons in the L4-L5 DRGs, a number not significantly different than controls (Table 1, Fig. 1). As expected, surviving neurons in DRGs of the $t r k A(-/-)$ animals are significantly larger than those in wild-type animals (Figs. 1, 2A). This tendency is striking, with elimination of virtually all neurons with soma areas smaller than $400 \mu \mathrm{m}^{2}$ in homozygous mutant mice. In contrast, size frequency histograms in heterozygous animals do not look significantly different than wild-type controls (Fig. 2A).

\section{Small myelinated and unmyelinated axons are massively depleted in homozygous but not heterozygous trkA mutant mice}

Axon caliber and myelination provide important information about the functional modality of dorsal root axons. 'These parameters have not been previously characterized in the $\operatorname{trkA}(-/-)$ or $\operatorname{NGF}(/)$ mutant micc. We therefore counted myelinated axons and constructed size-frequency histograms from semithin sections of dorsal roots (Figs. $2 B, 3$ ). Approximately $50 \%$ of the myelinated axons are lost in the trkA $(-/-)$ mice (Table 2). Many of the missing axons are in the size range $2-5 \mu \mathrm{m}^{2}$ (Figs. $2 B, 3$ ), which corresponds roughly to the size range of $A \delta$ fibers (see Boyd and Davey, 1968, for data from cat; Martin and Jessell, 1991, for data in human). In fact, $80 \%$ of axons in the $2-5 \mu \mathrm{m}^{2}$ are lust in $t r k A(-1$ -) mice. Thus, the majority of A $\delta$ axons are NGF-dependent. No such loss of small axons was observed in trkA $(+/-)$ animals (Figs. 2B, 3). Based on the size frequency histograms, it appears that some large-diameter axons are also lost in trkA(-/-) mutants, consistent with findings that some large-diameter DRG neurons express TrkA protein (Molliver et al., 1995).

More than $60 \%$ of DRG neurons have unmyelinated axons (Harper and Lawson, 1985; Hulsebosch et al., 1986). Although the majority of these neurons are involved in nociception, some mediate thermal and visceral processing (see Light, 1992, for a review). To assess the degree of loss of unmyelinated axons in the trkA $(-/-)$ animals, we analyzed the axonal composition of dorsal roots at the ultrastructural level (Fig. 4). Figure 4, $C$ and $D$, demonstrate the marked depletion of unmyelinated axons in the trkA (-/-) mice when compared to wild-type (Fig. 4A) and heterozyguus animals (Fig. $4 B$ ). In wild-type and heterozygous animals, unmyelinated axons were typically found in clusters containing $20-40$ axons. In contrast, in ( $-/-$ ) mutants, unmyelinated axons were found in isolation or in small clusters of only two to three axons. Axon counts from photomicrographs suggest that the loss of unmyelinated axons exceeds $95 \%$ in $(-1-)$ mutants. The few unmyelinated axons that remained had relatively large axonal diameters (Fig. $4 C, D$ ). Whether these fibers are involved in a specific physiological function, or represent a group of 

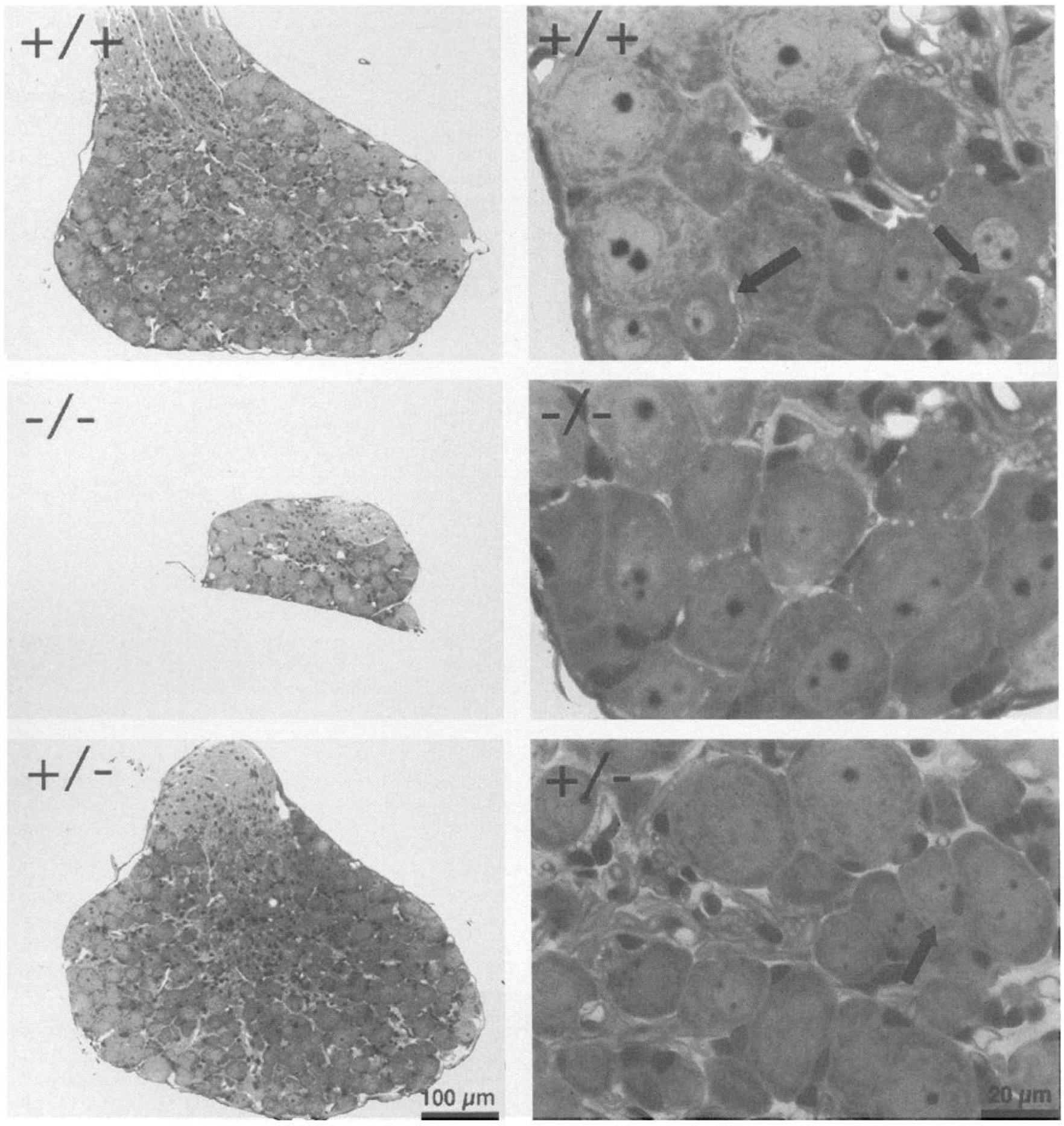

Figure 1. Semithin sections of DRGs from wild-type $(+/+)$, trkA homozygous $(-/-)$ and trkA heterozygous $(+/-)$ mutants. Left panel shows, at low magnification, the dramatic reduction in size of DRG sections from $(-/-)$ mice compared with wild-type $(+/+)$ controls. Note that there is little, if any, size difference between DRGs of $(+/-)$ compared to wild-type mice. The right panel shows, at higher magnification, that small neurons with darkly staining cytoplasm (arrows) are completely eliminated in the $(-/-)$ mutants when compared to $(+/+)$ animals. Again, numbers of small neurons in the heterozygous $(+/-)$ animals do not appear different from controls.

fibers that are just beginning to myelinate at this age (P15), is unknown.

Peptides associated with nociceptive functions are absent in $D R G s$ and dorsal horn in homozygous $\operatorname{trk} A$ mutant mice

Immunohistochemical labeling of sections from mutant mice using a panel of markers specific for different populations of DRG neurons revealed extensive loss of small-diameter peptidergic neurons and their projections to the superficial dorsal horn (Figs. $5,7)$. CGRP is a neuropeptide that has been implicated in nociceptive processing (see Hunt et al., 1992, for a review). Staining for CGRP is abundant in the wild-type DRG at P15 (Fig. $5 A$ ), and the dorsal horn projections of the CGRP-IR neurons were readily visualized (Fig. $5 B$ ). Note that CGRP labeling is 


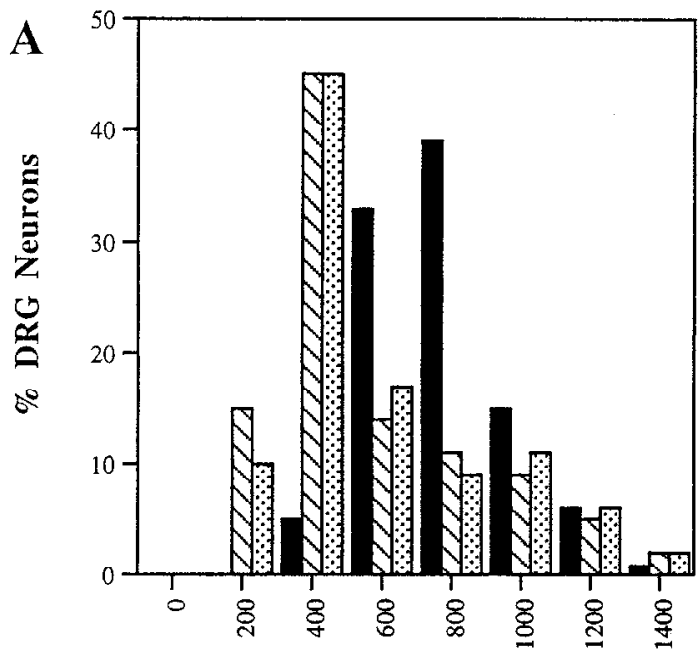

Area DRG Neurons $\left(\mu \mathrm{m}^{2}\right)$

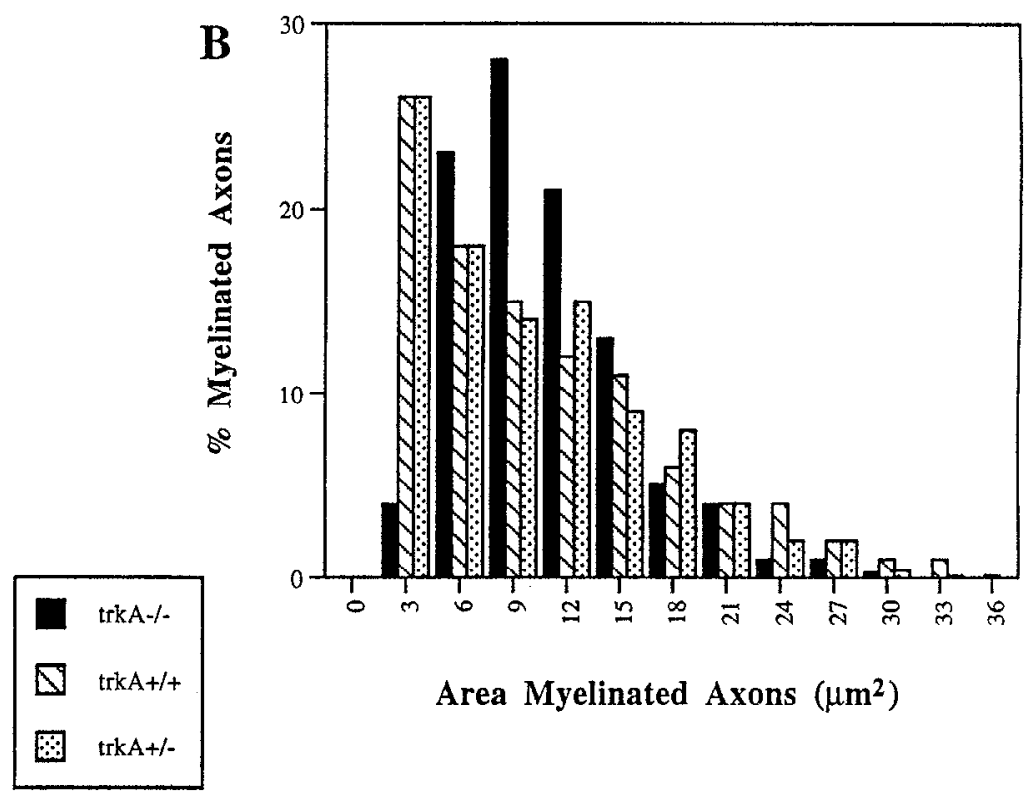

Figure 2. A, Size-frequency histograms of LA DRG neurons. Percentages of DRG neurons having a particular area ( $\left.\mu^{2}\right)$ are indicated by solid bars for the trkA $(-1-)$ mutant, by diagonal lines for the wild-type $(+1+)$ and by dots for the trkA $(+1-)$ mutant. Note that cells in the smallest size range are completely eliminated in the trkA $(-/-)$ mutants. In contrast, histograms from ( $+/-)$ animals look almost identical to wild type. Average soma size is $454 \perp 12 \mu \mathrm{m}^{2}$ in wild-type $(+/+), 482 \perp 13 \mu \mathrm{m}^{2}$ in $(+/-)$ and $670 \perp 13 \mu \mathrm{m}^{2}$ in $(-/-)$ mutant mice. $B$. Size- $1 \mathrm{requency}$ histograms of L4 dorsal root myelinated axons. Percentages of myelinated axons having a particular area $\left(\mu \mathrm{m}^{2}\right)$ in $(-/-),(+/+)$, and $(+/-)$ animals are as indicated. Almost $90 \%$ of the smallest myelinated fibers are absent from trkA homozygous animals. As with soma areas, no differences were observed between the trkA $(+/+)$ and the $\operatorname{trkA}(+/-)$ animals.

restricted to lamina I and the outer portion of lamina II (IIo), a pattern similar to that observed for TrkA (see Fig. 6D). CGRPIR in the mutant trkA (-/-) dorsal horn was virtually eliminated and few if any immunopositive DRG neurons were observed (Figs. $5 B, D$ ). Similarly, expression of SP, another peptide marker of nociceptive function, was also eliminated in the DRGs of P15 trkA (-/-) mice (Fig. 7E,F). Crowley et al. (1994) have reported similar findings in NGF $(-/-)$ mutant mice. Finally, immunoreactivity for peripherin, an intermediate filament protein frequently used as a marker for small DRG neurons with darkly staining cytoplasm ("small dark cells") (Parysek and Goldman, 1988), was also virtually eliminated in the DRG (data not shown).

\section{BSI-binding identifies DRG neurons which do not express}

TrkA, but are eliminated in $\operatorname{trk} A(-/-)$ mice

A large subpopulation of small DRG neurons with unmyelinated axons is known to bind BSI isolectins of the plant Bandeiraea simplicifolia (Silverman and Kruger, 1990; see Hunt et al., 1992, for a discussion of the primary literature). As expected from previous studies in rat, we observed that BSI robustly labels a large population of small-diameter DRG neurons and the entirety of lamina II in wild type animals (Figs. $5 E, G, 6 B-D$ ). In order to assess the potential NGF dependence of these lectin-positive neurons, we performed colocalization studies with BSI and a polyctonal antibody against the extracellular donain of TrkA (Rtk-Ex; see Materials and Methods) in $\mathrm{P} 15$ animals. TrkA protein is expressed by a minority of DRG neurons (roughly 45\%) with a range of sizes comparable to that observed for CGRP (compare Figs. 5A, 6A). The range of sizes of TrkA-positive neurons reflects the fact that neurons with both myelinated and unmyelinated axons are labeled. In spinal cord, TrkA axons innervate lamina I and IIo, corresponding to the pattern observed for CGRP. BSI neurons (Fig. 6B) are smaller than the largest
TrkA-neurons, presumably because BSI labels exclusively DRG neurons with unmyelinated axons. Interestingly, most of the BSI positive neurons do not exhibit colocalization with TrkA al P15 (Fig. 6C). Furthermore, in dorsal horn, BSI labeling includes the inner aspect of lamina II (IIi), an area that does not receive axons from TrkA-expressing neurons (Fig. 6D). These findings suggest that a substantial fraction of BSI-positive neurons do not express the signaling TrkA receptor and should be NGF-independent.

Surprisingly, no DRG neurons were labeled by BSI in P15 trkA (-l-) mutant mice (Fig. $5 F$ ). Furthermore, BSI labeling of lamina II in the spinal cord was completely abolished (Fig. $5 H$ ). That all lectin-binding neurons are eliminated in the $t r k \Lambda$ $(-/-)$ mutants indicates that a large group of DRG neurons which do not express TrkA in postnatal life are, in some manner, dependent on NGF/TrkA signaling during development.

All projections to superficial dorsal horn are absent within the spinal cord of the trkA knockout mice

The massive loss of peptidergic and lectin-binding neurons as well as loss of small-diameter myelinated and unmyelinated axons in the trkA $(-/-)$ mutants should virtually eliminate the dorsal root projection to laminae I and II of the dorsal horn (see Fyffe, 1992, for a review of primary afferent projections to dorsal horn). To determine whether any classes of dorsal root axons remained in the superficial dorsal horn of $\operatorname{trkA}(-1-)$ animals, we labeled this projection in its entirety with the lipid-soluble tracer DiI. For technical reasons, these experiments were performed at E17.5 (see Materials and Methods). Although occasional axons were observed in laminae I and II in these preparations, it was apparent that the vast majority of the dorsal root projection was eliminated in the trkA (-/-) mice (Fig. $7 A, B$ ). In contrast, the central projections of two other major groups of dorsal root axons (proprioceptive afferents and afferents from low-threshold mechanoreceptors) were not obviously affected. 

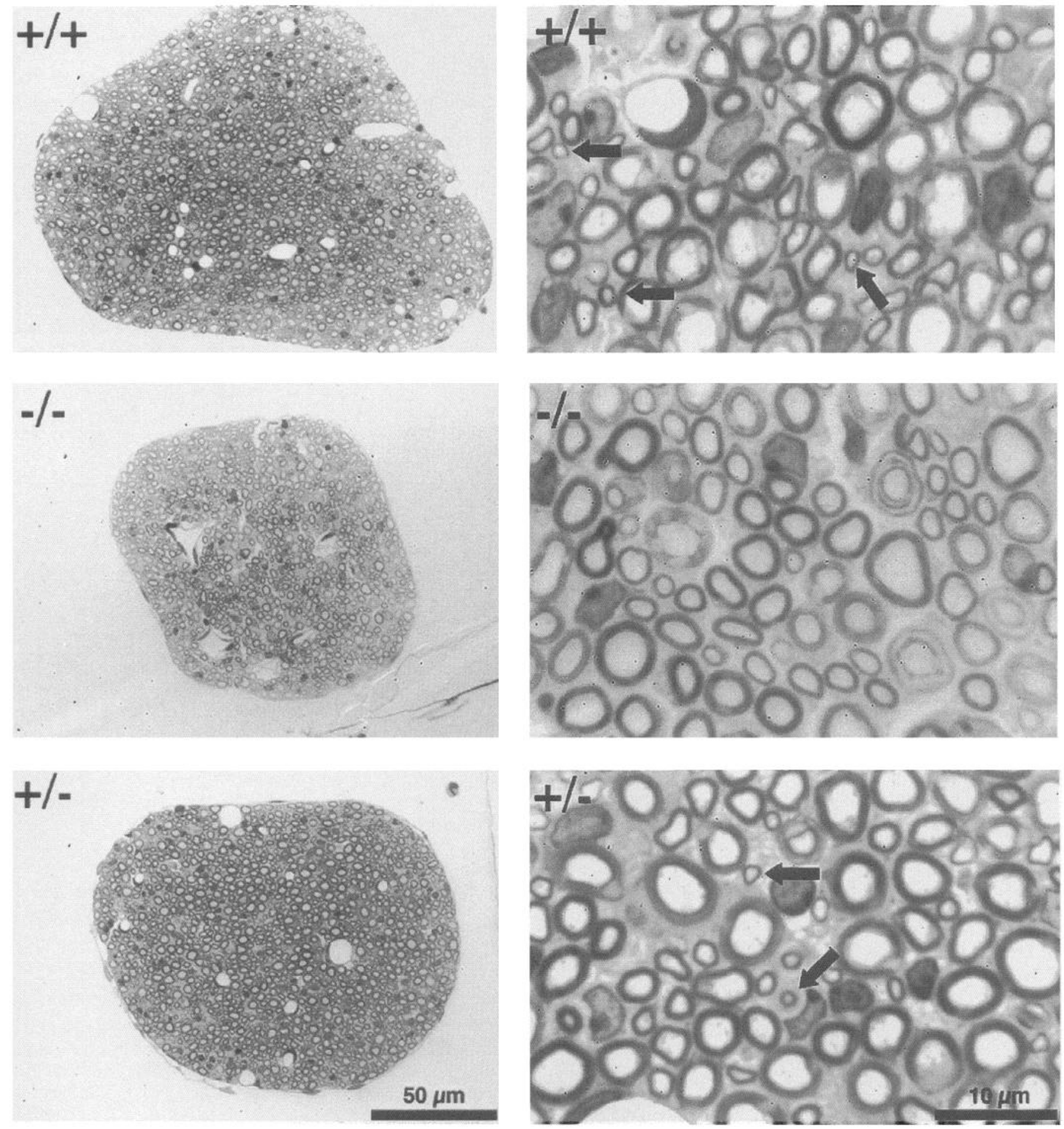

Figure 3. Semithin sections of L4 dorsal roots from wild-type $(+/+)$, trkA homozygous $(-/-)$ and trkA heterozygous (+/-) mutants. Left panel shows, at low magnification, the size differences in the dorsal root from the wild-type $(+/+)$ mice compared with $(-/-)$ and $(+/-)$ mutants. Note that the size reduction in the dorsal roots of trkA (-l-) mutants is not so dramatic as observed for the ganglion. This is presumably because root size is mainly determined by the numbers of the large myelinated axons, which are not reduced in trkA $(-1-)$ animals. The right panel shows, at higher magnification, that the smallest myelinated fibers (arrows) are absent in the $(-/-)$ mutants when compared to $(+/+)$ and $(+/-)$ animals.

Placing DiI crystals in the skin allows a particularly clear view of innervation of a restricted region of dorsal horn (Fig. $7 C$ ). In these preparations, we observed only rare axons in laminae $\mathrm{I}$ and II in trkA $(-/-)$ mutant animals, in contrast to the dense innervation that is already present in wild-type controls by E17 (Fig. $7 C, D$ ). The primary afferent projection to laminae III and IV appeared relatively normal in the trkA $(-/-)$ animals. All of these findings agree with results of a previous study in rats treated with anti-NGF antibodies during development (Ruit et al., 1992). The absence of projections to laminae I and II at 
Table 2. Numbers of myelinated axons in L4 dorsal roots at P13-P15

\begin{tabular}{llll} 
GN & $\begin{array}{l}\text { No. DR axons } \\
(\text { mean } \pm \text { SEM) }\end{array}$ & $\%$ & $\begin{array}{l}\text { No. of } \\
\text { animals } \\
\text { examined }\end{array}$ \\
\hline$(+/+)$ & $2031 \pm 184$ & 100 & 3 \\
$(+/-)$ & $1626+136$ & 80 & 3 \\
$(-/-)$ & $1043 \pm 57^{*}$ & 51 & 3 \\
\hline
\end{tabular}

GN, Genotype.

*Differs from $(+1+), p<0.05$.

E17.5 shows that the DRG neuron loss in the trkA (-/-) mutants occurs early in embryonic development (see Silos-Santiago et al., 1994).

\section{Surviving DRG neurons in trkA-deficient mice contain phosphorylated $\mathrm{NFH}$}

In contrast to the virtual elimination of neuropeptides and lectin markers, numbers of DRG neurons expressing cytochemical markers associated with "large light" DRG neurons were not substantially altered in trkA $(-1-)$ mice. Thus, antibodies to the phosphorylated high molecular weight neurofilament protein (NFH; see Lawson, 1992, for a review) revealed a relatively normal complement of "large light" neurons in trkA $(-/-)$ mutants (Fig. $7 G, H$ ). Particularly of interest is that virtually all remaining neurons in the DRGs of trkA $(-/-)$ animals stained with antibodies against NFH (Fig. $7 H$ ). As expected, many DRG neurons in trkA $(-/-)$ animals stained with antibodies against parvalbumin (data not shown), which is now known to be a selective marker for proprioceptive neurons (Ernfors et al., 1994b).

Finally, in order to determine whether all remaining neurons express a member of the Trk family, we performed in situ hybridization with probes against $t r k \mathrm{~B}$ and $t r k \mathrm{C}$. In agreement with previous studies, substantial numbers of neurons which expressed $t r k \mathrm{~B}$ and $t r k \mathrm{C}$ were observed (Carroll et al., 1992; Crowley et al., 1994). Interestingly, when both $\operatorname{trk} \mathrm{B}$ and $t r k \mathrm{C}$ were hybridized together, few, if any, unlabeled neurons were observed in the DRGs of trkA (-l-) animals (Fig. 8). This latter finding demonstrates that the $25-35 \%$ of DRG neurons which express no neurotrophin receptors (McMahon et al., 1994; Wright and Snider, 1995) in maturity, are actually NGF-dependent during development. This result suggests that the non-neurotrophin receptor group is identical to the group of non-trkA expressing neurons which bind BSI.

\section{Discussion}

In this study, we have shown that virtually all DRG neurons associated with nociceptive functions on the basis of morphological criteria are lost in the trkA $(-/-)$ mutant mice. In addition, we show that many small neurons in the DRG which bind BSI isolectins do not express the signaling NGF receptor, TrkA, and therefore should be NGF-independent. These neurons almost certainly correspond to a group of $25-35 \%$ of small DRG neurons which do not express any known member of the Trk family in postnatal animals (McMahon et al., 1994; Wright and Snider, 1995). Surprisingly, inactivation of the trkA gene by homologous recombination leads to total elimination of these small, lectin-binding DRG neurons.
NGF/TrkA-signaling regulates survival of both peptidergic and BSI-binding DRG neurons

Our findings are entirely consistent with the current view that primary sensory neurons with nociceptive functions require NGF for survival during development (Johnson et al., 1980; Otten et al., 1980; Goedert et al., 1984; Yip et al., 1984; Carroll et al., 1992; Ruit et al., 1992; Crowley et al., 1994; Smeyne et al., 1994). Furthermore, we show here that all populations of DRG neurons which have been associated with nociceptive functions on the basis of morphological and histochemical criteria require TrkA receptors for survival at some developmental stage. Thus, virtually all neurons with soma areas $<400 \mu \mathrm{m}^{2}$, almost all DRG neurons with unmyelinated and small-diameter myelinated axons, the entire projection to lamina I and II, all neurons expressing CGRP and SP, all neurons binding BSI, and neurons expressing the intermediate filament, peripherin, are lost in $\operatorname{trk\mathrm {A}}(-/-)$ mutant mice. Although we have not determined the physiological characteristics of the remaining dorsal root axons in these animals, our morphological findings are consistent with the loss of most $A \delta$ axons and virtually the entire C-fiber population. We thus demonstrate that the dependence of nociceptive neurons on NGF/TrkA signaling during development is all-inclusive: we could find no evidence that any subpopulations of DRG neurons with presumed nociceptive functions on the basis of morphological criteria survive elimination of TrkA receptors. 'l'he decreased responsiveness to pain, the appearance of scabs and ulcerations on the body and paws, and the selfmutilation phenomena observed in neonatal animals that have been deprived of NGF/TrkA signaling by antibodies or gene targeting are entirely consistent with this interpretation (Johnson et al., 1980; Crowley et al., 1994; Smeyne et al., 1994).

The NGF-dependence of DRG neurons binding BSI is of particular interest. These neurons largely overlap with those that express the cytoplasmic enzyme fluoride-resistant acid phosphatase (FRAP) (McMahon, 1986; Silverman and Kruger, 1990; see Hunt et al., 1992, for a review). Most of these are thought to be polymodal nociceptors (Lawson, 1992), but they have two distinguishing characteristics. First, although there is controversy on this point, most BSI-binding DRG neurons appear not to express CGRP or SP (see Hunt et al., 1992, for a review of the primary literature). Second, many BSI-binding neurons (and those expressing FRAP) project to the inner part of lamina II, an area not innervated by CGRP, SP, or TrkA axons. Thus, at least some BSI neurons must have different functions than the peptidergic, TrkA-expressing population. Interestingly, the majority of neurons in the inner portion of lamina II have been shown by several investigators to respond to innocuous mechanical stimulation, rather than to nociceptive stimuli (for reviews, see Perl, 1984; Willis and Coggeshall, 1991; Light, 1992). Consistent with this idea is the finding that non-nociceptive C-fibers account for $20-30 \%$ of the unmyelinated axons in rat (Lynn and Carpenter, 1982). That some of these neurons may be NGF-independent in maturity is underscored by the findings of Lewin and Mendell (1994), who showed that the effects of postnatal NGF or anti-NGF administration are largely selective for a subset of $\mathrm{C}$-fibers comprising the mechanoheat polymodal nociceptors, with little or no effect on non-nociceptive C-fibers. Clearly, however, these small, non-nociceptive DRG neurons which encode innocuous thermal or low-threshold mechanoreceptive stimuli must be NGF-dependent during embryonic development, as they are lost in the $\operatorname{trk} A(-1-)$ mutants. 

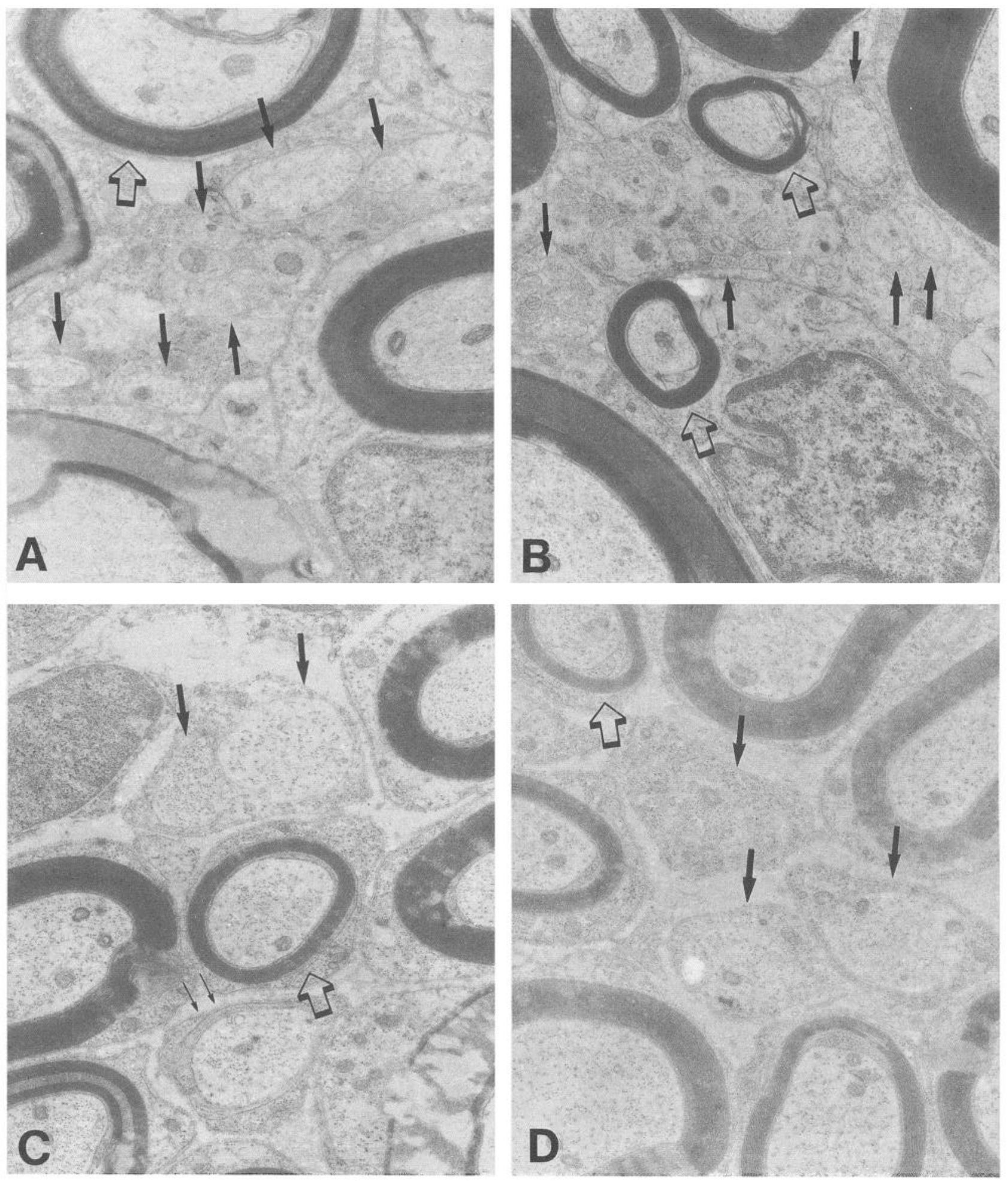

Figure 4. Electron microphotographs showing both myelinated and unmyelinated axons in the dorsal roots from $A$, wild type $(+/+) ; B$, heterozygous (+I-); $C$ and $D$, homozygous ( $-/-$ ) mice. $A$ and $B$ show normal clusters of nonmyelinated axons (arrows) surrounded by myelinated fibers (open arrows) in the $(+/+)$ and $(+/-)$ mice. The arrows point out only a fraction of the many small, unmyelinated axons that are present in the fields. $C$ and $D$ show that in the (-I-) mice only a few unmyelinated axons (arrows) remain. These axons are large in diameter compared to unmyelinated axons in control mice and are not clustered. One fiber in an early stage of myelination is shown in the trkA ( $/-)$ mutant $(C$, thin arrows). Magnification 20,000×. 

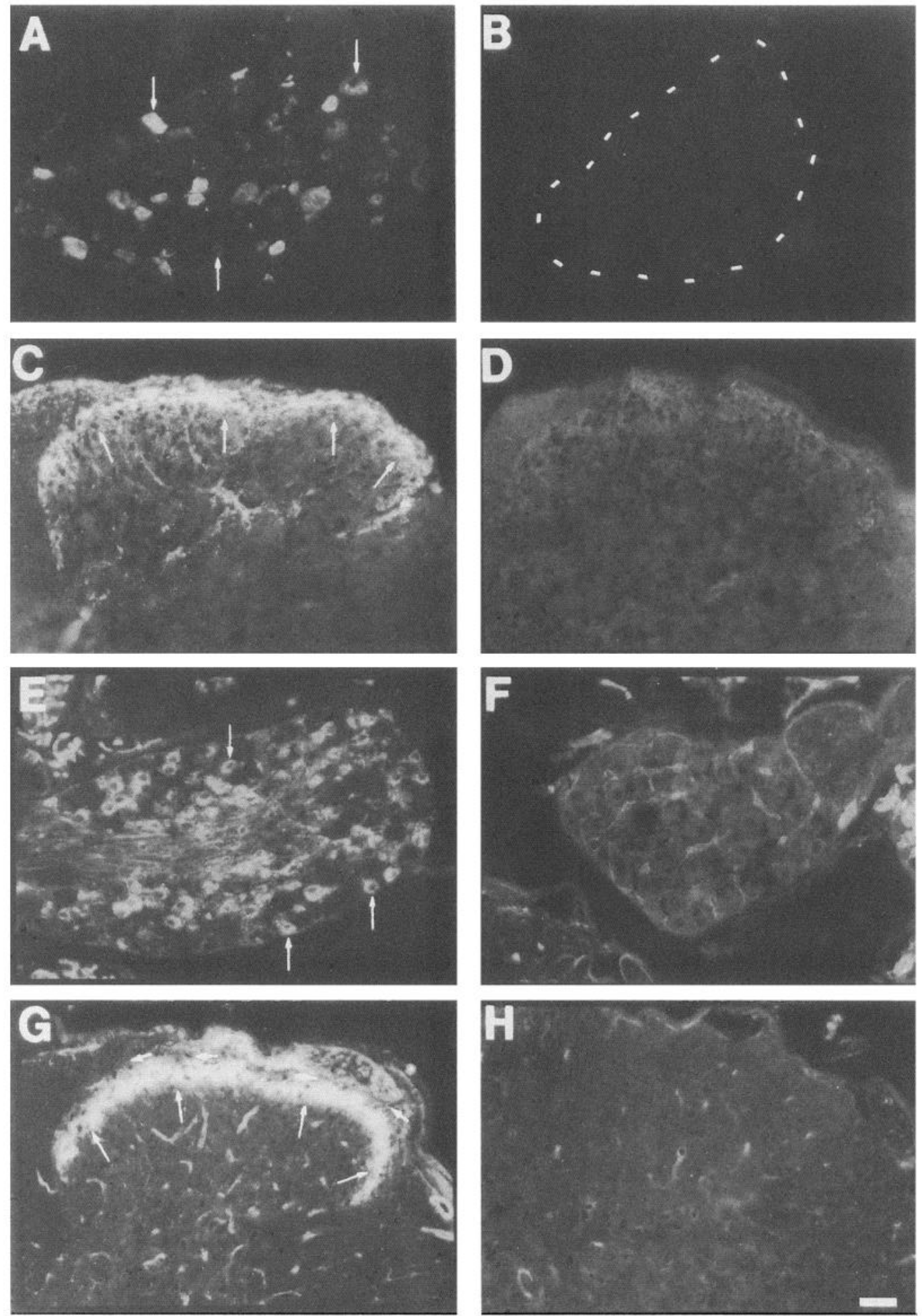

Figure 5. Transverse sections of DRGs and spinal cord illustrating immunoreactive DRG neurons for CGRP and BSI. A, DRG from wild type mice showing CGRP-IR neurons (arrows). B, In the trkA $(-1-)$, mutant all CGRP-positive DRG neurons have been eliminated. Outline of the DRG is shown with dashed lines. C, CGRP immunoreactivity is present in the superficial laminae (I and IIo) of the dorsal horn as well as in lamina V. Arrows denote the inner border of lamina IIo. D, CGRP is completely absent from the spinal cord of the trkA ( $-/-)$ mutant. $E$, BSI labels a large population of small DRG neurons (arrows) in wild type mouse. $F$. All BSI positive DRG neurons are absent in the trkA (-I-) mouse. G, BSI labels the entirety of lamina II of the superficial dorsal horn (lower arrows). Lamina I is not stained (small upper arrows). H, BSI labeling in spinal cord is also has been eliminated in the trkA(-/-) mutant mice. Scale bar, $50 \mu \mathrm{m}$. 

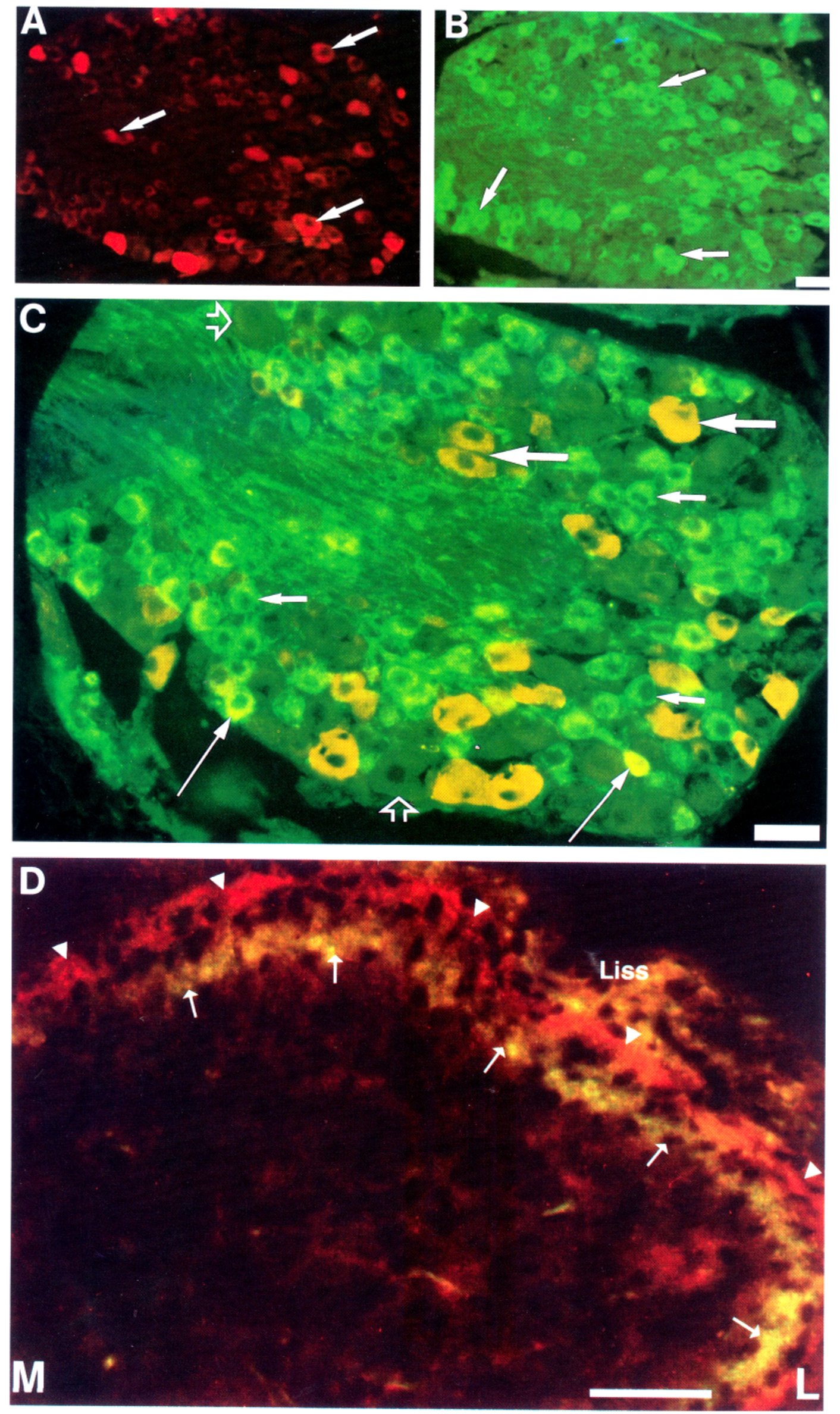

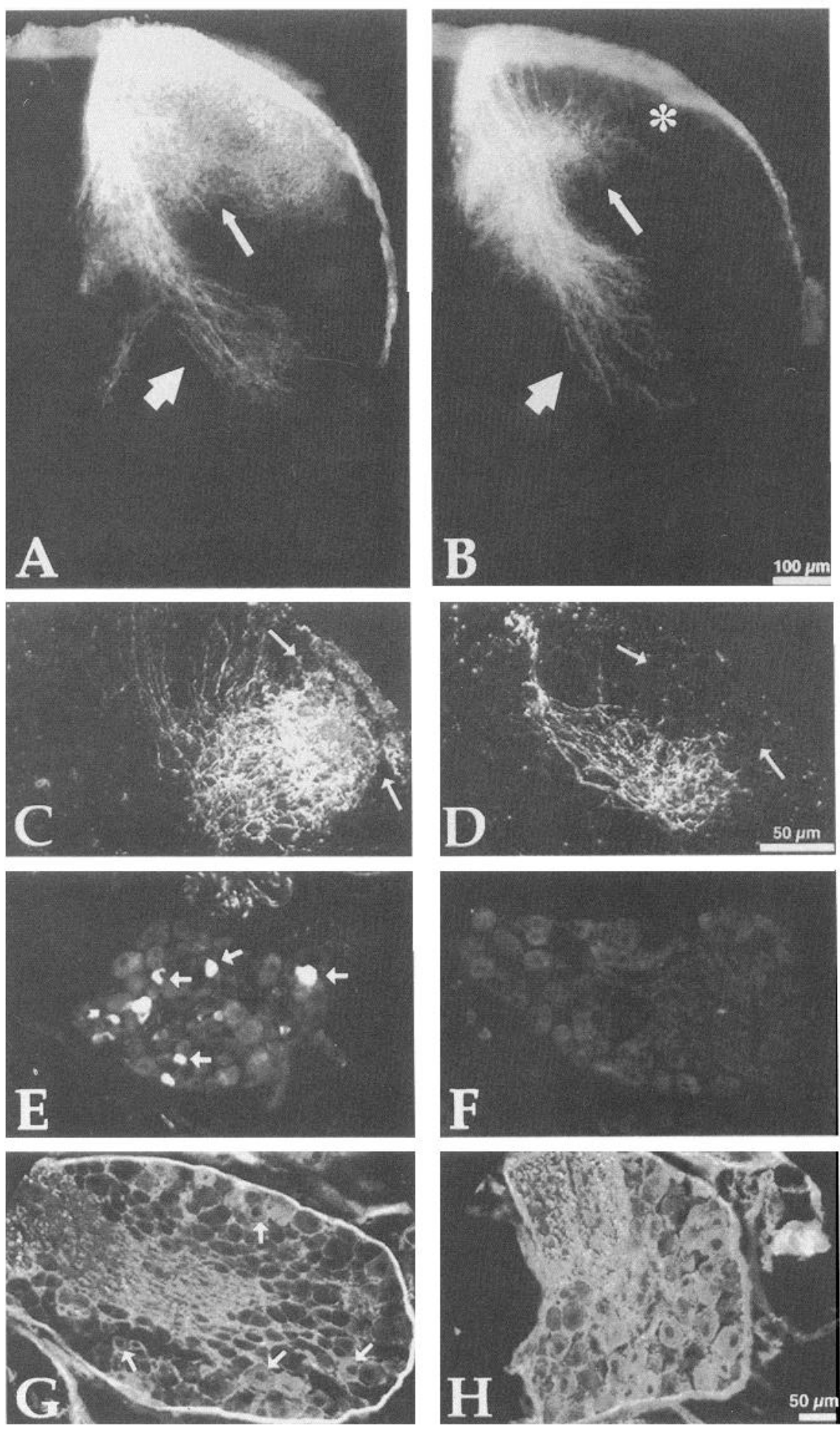

Figure 7. $A-D$, Transverse sections of the spinal cord illustrating the dorsal root projection, labeled with DiI, in a wild-type $(A, C)$ and trkA mutants $(-1-)$ $(B, D)$. In wild-type mice $(A)$, Ia afferents (thick arrow), hair-follicles afferents (long arrow), as well as fine cutaneous afferents (asterisk) are present in the gray matter of the spinal cord. In contrast, in the trkA $(-/-)$ mice $(B)$ fine cutaneous afferents innervating laminae I and II of the spinal cord are absent (asterisk). In contrast, la (thick arrow) and hair-follicle afferents (long arrow), appear relatively unaffected. $C$ and $D$ show transverse sections of the spinal cord where the dorsal root projection has been labeled with $\mathrm{Dil}$ from the skin and photoconverted with DAB. $C$, wild type. Note that both superficial laminae (I and II, arrows) as well to deeper laminae (III and IV) of the dorsal horn are densely innervated. $B$, trkA (-I-). Notice that no axons project to laminae I and II (arrows). In contrast, the projection to laminae III and IV appears normal. $E-H$, Transverse sections of DRGs illustrating immunoreactive DRG neurons for SP and NFH. $E$, DRG from wild type mice showing SP-IR neurons (arrows). $F$, In the trkA (-l-) mutant all SP-positive DRG neurons have been eliminated. $G$, NFH labels a population of large DRG neurons in wild type mouse (small arrows), while a large population of small DRG neurons are NFH negative. $H$, Note that all remaining DRG neurons in the trkA $(-/-)$ mutant are NFH positive.

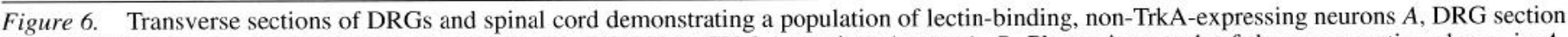

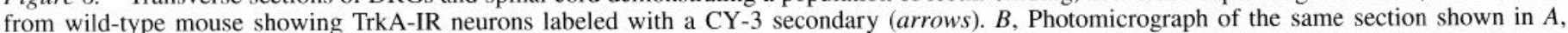

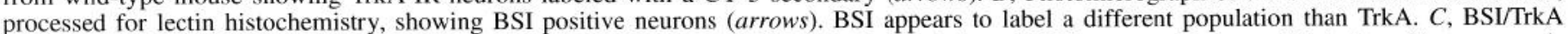

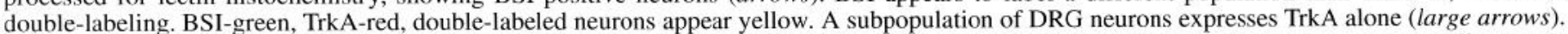

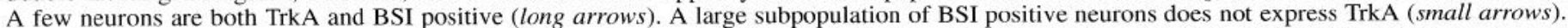

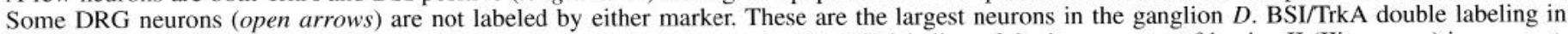

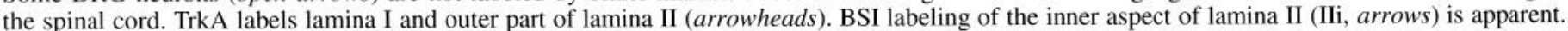
BSI also labels Lissauer's tract (Liss). $M$, Medial; $L$, lateral. Scale bars, $40 \mu \mathrm{m}$. 

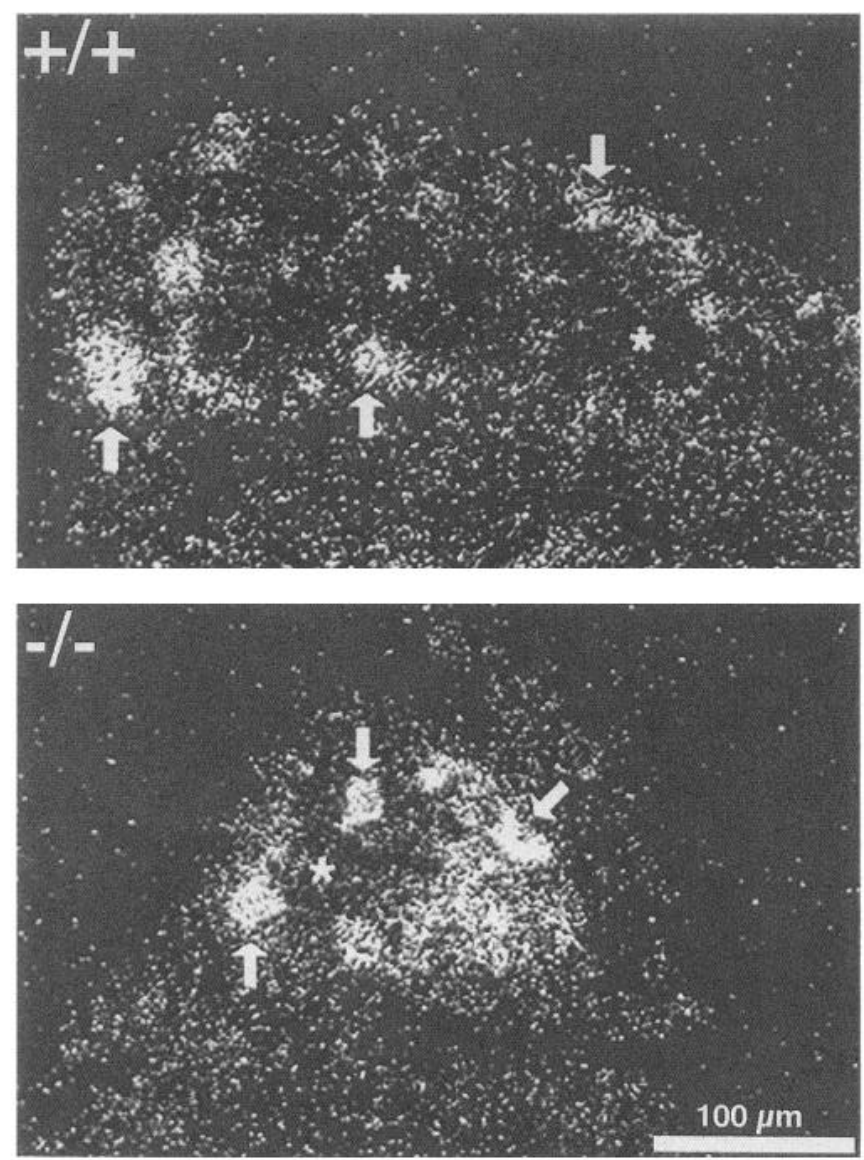

Figure 8. Dark-field photomicrographs of DRG sections from trkA $(+/+)$ and trkA $(-/-)$ animals hybridized with probes against both trkB and trkC. In DRGs from $(+/+)$ animals, neurons which express either $t r k \mathrm{~B}$ or $t r k \mathrm{C}$ at high levels are readily apparent (arrows). However, regions of the ganglion which show no hybridization are also observed. Bright-field examination of these areas shows numerous neurons which do not hybridize with either the $t r k \mathrm{~B}$ or $t r k \mathrm{C}$ probes. In contrast, all neurons in $(-/-)$ animals show hybridization when the trk $\mathrm{B} /$ trkC probe mixture is used (arrows). Asterisks denote areas in the center of the ganglia containing axons and Schwann cells.

A surprising feature of our findings is that the heterozygous trkA mutants exhibit little if any DRG neuron loss. It is clear from our results that trkA is the primary mediator of the survival-promoting actions of NGF in vivo (see also Smeyne et al., 1994). If current ideas are correct about neuronal number being, in part, determined by limiting quantities of growth factors during development (see Oppenheim, 1991, for a review), one would predict that decreases in receptor number, as should occur in trkA (+/-) animals, would have a substantial impact on neuron survival. Indeed, in animals heterozygous for a mutation in the NT-3 locus, the number of proprioceptive afferents appears to be reduced by $50 \%$ (Ernfors et al., 1994b). Although there was a trend toward smaller numbers of DRG neurons in the $t r k \mathrm{~A}$ $(+/-)$ animals, it did not reach significance. Furthermore, sizefrequency histograms did not show atrophy of remaining neurons or axons. Crowley et al. (1994) also noted little DRG neuron loss in mice heterozygous for a NGF mutation. The reasons for this discrepancy in effects of heterozygosity for an NT-3 mutation compared to heterozygosity for NGF or trkA mutations are unclear. For example, we do not yet know to what extent numbers of TrkA receptors are actually reduced in the trkA $(+/-)$ animals, or growth factor levels are actually reduced in NGF $(+/-)$ and NT-3 (+/-) animals. It is also important that growth factor requirements for nonsurvival functions may be as much as 100-fold greater than growth factor requirements for survival (Verdi et al., 1994). Thus, it is entirely possible that DRG neurons in heterozygous animals will exhibit subtle, but physiologically significant changes in functional properties (see Crowley et al., 1994).

\section{$N G F$ dependence of non-TrkA expressing DRG neurons}

A major surprise in the current study is that many of the lectinbinding DRG neurons which require TrkA receptors for survival during development do not express TrkA in maturity. This DRG subpopulation is the first characterized example of a neuronal class in which the signaling NGF receptor, TrkA, is not expressed, but the neurons are nevertheless dependent on NGF. Our findings explain the large discrepancy between the percentages of DRG neurons reported to express TrkA (40-50\%) and the percentages of DRG neurons reported lost in the setting of NGF deprivation $(70-85 \%)$.

It is possible that previous studies have underestimated the percentage of TrkA-expressing neurons due to insensitivity of methods for detecting TrkA expression. This seems unlikely for three reasons. First, all previous investigations aimed at detecting either TrkA protein or mRNA have arrived at very similar percentages (40-50\%) of TrkA-expressing neurons in the adult rat DRG (Verge et al., 1992; Ernfors et al., 1993; Averill et al., 1994; Molliver et al., 1995; see also Mu et al., 1993a; McMahon et al., 1994; Wright and Snider, 1995). Second, studies determining percentages of DRG neurons exhibiting high-affinity NGF binding have also arrived at a figure of approximately $45 \%$ (Verge et al., 1989). Finally, two studies using a "cocktail" of neurotrophin receptor probes have agreed in finding that 25$35 \%$ of DRG neurons express no neurotrophin receptor (McMahon et al., 1994; Wright and Snider, 1995). The non-TrkA expressing, lectin-binding neurons almost certainly correspond to the $25-35 \%$ of DRG neurons with small soma areas which do not express p75 or any known member of the Trk receptor family (McMahon et al., 1994; Wright and Snider, 1995).

At least two explanations may account for the NGF-dependence of non-TrkA expressing DRG neurons. First, non-TrkAexpressing neurons may be indirectly dependent on NGF for their survival. It is known that at least one neurotrophin, BDNF, is expressed within the DRG (Ernfors and Persson, 1991; Schecterson and Bothwell, 1992), and preliminary results suggest that BDNF expression is regulated by NGF (Apfel et al., 1994). It is therefore possible that non-TrkA-expressing neurons in the ganglia are dependent on another growth factor synthesized by TrkA-expressing neurons. Although such a scenario seems plausible, no studies in vivo have yet documented neuron loss due to this type of paracrine growth factor dependence. Indeed, the massive loss of NGF-dependent neurons observed in NGF $(-/-)$ and $\operatorname{trkA}(-/-)$ mice appears to have little effect on neighboring NT-3-dependent proprioceptive neurons within the DRG.

An alternative explanation is that small, lectin-binding neurons exhibit plasticity of trkA expression during development. Indeed, developmental changes in neuronal expression of surface molecules, amino acid receptors, and transmitter phenotypes are integral to neural development. With regard to neurotrophin receptors, trkC expression is robust at very early developmental stages in sympathetic ganglia, and then downregulated around the time $\operatorname{trkA}$ expression appears (Birren et al., 
1993; sec also DiCicco-Bloom ct al., 1993). There is also very strong evidence that NT-3 has important functions in regulating survival of sensory neurons which later become NGF-dependent in both mouse and quail (Buchman and Davies, 1993; see also Gaese et al., 1994). In all of these systems, it is hypothesized that neurons switch neurotrophin dependence around the time their axons reach target fields, which is their primary source of NGF (see Birren et al., 1993; Buchman and Davies, 1993). Important in this regard is that many of the BSI-binding DRG neurons innervate skin (Hunt et al., 1992) which is known to be a rich source of NGF during development (Schecterson and Bothwell, 1992). A subsequent switch from dependence on NGF to dependence on other growth factors has not been previously described, and does not fit neatly into this theoretical framework. Nevertheless, expression of trkA in $\mathrm{DKG}$, like that of $t r k \mathrm{C}$, appears very diffuse at early developmental stages (Ernfors et al., 1992; Zhang et al., 1994), consistent with the idca that cxpression of TrkA receptors in many DRG neurons may be downregulated as development proceeds.

\section{References}

Apfel SC, Dormia C, Newell ME, Kessler JA (1994) Nerve growth factor administration alters the expression of other neurotrophins in adult sensory ganglia. Soc Neurosci Abstr 20:1302.

Averill S, McMahon SB, Clary DO, Reichard LF, Priestley JV (1994) trkA immunohistochemistry in adult rat dorsal root ganglia. Soc Neurosci Abstr 20:34.

Birren SJ, Lo L, Anderson DJ (1993) Sympathetic neuroblasts undergo a developmental switch in trophic dependence. Development 119 : $597-610$.

Boyd IA, Davey MR (1968) Composition of peripheral nerves. Edinburgh: Livingstone.

Buchman VL, Davies AM (1993) Different neurotrophins are expressed and act in a developmental sequence to promote the survival of embryonic sensory system. Development 118:989-1001.

Carroll SL, Silos-Santiago I, Frese SE, Ruit KG, Milbrandt J, Snider WD (1992) Dorsal root ganglia neurons expressing trk are selectively sensitive to NGF deprivation in utero. Neuron 9:779-788.

Clary DO, Weskamp G, Austin LR, Reichardt LF (1994) TrkA crosslinking mimics neuronal responses to nerve growth factor. Mol Biol Cell 5:549-563.

Crowley C, Spencer SD, Nishimura MC, Chen KS, Pitts-Meek S, Armanini MP, Ling LH, McMahon SB, Shelton DI, I evinson AD, Phillips HS (1994) Mice lacking nerve growth factor display perinatal loss of sensory and sympathetic neurons yet develop basal forebrain cholinergic neurons. Cell 76:1001-1011.

DiCicco-Bloom E, Friedman WJ, Black IB (1993) NT-3 stimulates sympathetic neuroblast proliferation by promoting precursor survival Neuron 11:1011-1111.

Eide FF, Lowenstein DH, Reichardt LF (1993) Neurotrophins and their receptors: current concepts and implications for neurologic disease. Exp Neurol 121:200-214.

Ernfors P, Persson H (1991) Developmentally regulated expression of HDNF/NT-3 mRNA in rat spinal cord motor neurons and expression of BDNF mRNA in embryonic dorsal root ganglion. Eur J Neurosci 3:953-961.

Ernfors P, Merlio J-P, Persson H (1992) Cells expressing mRNA for neurotrophins and their receptors during embryonic rat development. Eur J Neurosci 4:1140-1158.

Enfors P, Rosario CM, Merlio J-P, Grant G, Aldskogius H, Persson H (1993) Expression of mRNAs for neurotrophin receptors in the dorsal root ganglion and spinal cord during development and following peripheral or central axotomy. Mol Brain Res 17:217-223.

Ernfors P, Lee K-F, Jaenisch R (1994a) Mice lacking brain-derived neurotrophic factor develop with sensory deficits. Nature 368:147150.

Ernfors P, Lee K-F, Kucera J, Jaenisch R (1994b) Lack of neurotrophin-3 leads to deficiencies in the peripheral nervous system and loss of limb proprioceptive afferents. Cell 77:503-512.

Fariñas I, Jones KR, Backus C, Wang X-Y, Reichardt LF (1994) Severe sensory and sympathetic deficits in mice lacking neurotrophin-3. Nature 369:658-661.

Fyffe REW (1992) Laminar organization of primary afferent terminations in mammalian spinal cord. In: Sensory neurons. Diversity, development and plasticity (Scott SA, ed), pp 131-139. New York: Oxford UP.

Gaese F, Kolbeck R, Barde Y-A (1994) Sensory ganglia require neurotrophin-3 early in development. Development 120:1613-1619.

Goedert M, Otten U, Hunt SP, Bond A, Chapman D, Schlumpf M, Lichtensteiger N (1984) Biochemical and anatomical effects on antibodies against nerve growth factor on developing rat sensory ganglia. Proc Natl Acad Sci USA 81:1580-1584.

Harper AA, Lawson SN (1985) Conduction velocity is related to morphological cell type in rat dorsal root ganglion neurones. J Physiol (Lond) 359:31-46.

Hulsebosch CE, Coggeshall RE, Chung K (1986) Numbers of rat dorsal root axons and ganglion cells during postnatal development. Dev Brain Res 26:105-113.

Hunt SP, Mantyh PW, Priestley JV (1992) The organization of biochemically characterized sensory neurons. In: Sensory neurons. Diversity, development and plasticity (Scott SA, ed), pp 60-76. New York: Oxford UP.

Johnson EM, Gorin PD, Brandeis LD, Pearson J (1980) Dorsal root ganglion neurons are destroyed by exposure in utero to maternal antibody to nerve growth factor. Science 219:916-918.

Jones KR, Fariñas I, Backus C, Reichardt LF (1991) Targeted disruption of the BDNF gene perturbs brain and sensory neuron development but not motor neuron development. Cell 76:989-999.

Kessler JA, Black IB (1980) Nerve growth factor stimulates the development of substance $P$ in sensory ganglia. Proc Natl Acad Sci USA 77:649-652.

Klein R, Smeyne RJ, Wurst W, Long LK, Auerbach BA, Joyner AL, Barbacid M (1993) Targeted disruption of the $t r k B$ neurotrophin receptor gene results in nervous system lesions and neonatal death. Cell 75:113-122.

Klein R, Silos-Santiago I, Smeyne RJ, Lira SA, Brambilla R, Bryant S, Zhang L, Snider WD, Barbacid M (1994) Disruption of the neurotrophin-3 receptor gene $t r k \mathrm{C}$ eliminates Ia muscle afferents and results in abnormal movements. Nature 368:249-251.

Koerber HR, Mendell LM (1992) Functional heterogeneity of dorsal root ganglion cells. In: Sensory neurons. Diversity, development and plasticity (Scott SA, ed), pp 77-96. New York: Oxford UP.

Korsching S (1993) The neurotrophic factor concept: a reexamination. J Neurosci 13:2739-2748.

Landis SC (1990) Target regulation of neurotransmitter phenotype. Trends Neurosci 13:344-350.

Landis SC, Keefe D (1983) Evidence for neurotransmitter plasticity in vivo: developmental changes in properties of cholinergic sympathetic neurons. Dev Biol 98:349-372.

Lawson SN (1992) Morphological and biochemical cell types of sensory neurons. In: Sensory neurons. Diversity, development and plasticity (Scott SA, ed), pp 27-59. New York: Oxford UP.

Lewin GR, Mendell LM (1993) Nerve growth factor and nociception. Trends Neurosci 16:353-359.

Lewin GR, Mendell LM (1994) Regulation of cutaneous C-fiber heat nociceptors by nerve growth factor in the developing rat. J Neurophysiol 71:941-949.

Light AR (1992) The initial processing of pain and its descending control: spinal and trigeminal systems. In: Pain and headache, Vol 12 (Gildenberg PL, ed). Basel: Karger.

Lynn B, Carpenter SE (1982) Primary afferent units from the hairy skin of the rat hind limb. Brain Res 238:29 43 .

Martin JH, Jessell TM (1991) Modality coding in the somatic sensory system. In: Principles of neural science, Chap 24, Sensory systems of the brain: sensation and perception, Pt V (Kandel E, et al., eds), pp 341-352. New York: Elsevier.

McMahon SB (1986) The localization of fluoride-resistant acid phosphatase (FRAP) in the pelvic nerves and sacral spinal cord of rats. Neurosci Lett 64:305-310.

McMahon SB, Armanini MP, Ling LH, Phillips HS (1994) Expression and coexpression of trk receptors in subpopulations of adult primary sensory neurons projecting to identified peripheral targets. Neuron 12:1161-1171.

Molliver DC, Radeke MJ, Feinstein SC, Snider WD (1995) Presence or absence of TrkA protein distinguishes subsets of small sensory 
neurons with unique cytochemical characteristics and dorsal horn projections. J Comp Neurol, in press.

Mu X, Silos-Santiago I, Carroll SL, Snider WD (1993a) Neurotrophin receptor genes are expressed in distinct patterns in developing dorsal root ganglia. J Neurosci 13:4029-4041.

Mu X, Silos-Santiago I, Gerfen R, Snider WD (1993b) Neurotrophin receptor gene expression in developing DRG. Soc Neurosci Abstr 19: 1300.

Oppenheim RW (1991) Cell death during development of the nervous system. Annu Rev Neurosci 14:453-501.

Otten U, Goedert M, Mayer N, Lembeck F (1980) Requirement of nerve growth factor for development of substance P-containing sensory neurons. Nature 287:158-159.

Parysek LM, Goldman RD (1988) Distribution of a novel $57 \mathrm{kDa}$ intermediate filament (IF) protein in the nervous system. $\mathbf{J}$ Neurosci $8: 555-563$.

Perl ER (1984) Pain and nociception. In: Handbook of physiology, Sec I, The nervous system, Vol III, Sensory processes, Pl 2 (Darian-Smith I, ed), pp 915-975. Bethesda, MD: American Physiological Society.

Perl ER (1992) Function of dorsal root ganglion neurons: An overview. In: Sensory neurons. Diversity, development and plasticity (Scott SA, ed), pp 3-23. New York: Oxford UP.

Ruit KG, Elliott JL, Osborne PA, Yan Q, Snider WD (1992) Selective dependence of mammalian dorsal root ganglion neurons on nerve growth factor during embryonic development. Neuron 8:573-587.

Sandell JH, Masland RH (1988) Photoconversion of some fluorescent markers to a diaminobenzidine product. J Histochem Cytochem 36: 555-559.

Schecterson LC, Bothwell M (1992) Novel roles for neurotrophins are suggested by BDNF and NT-3 mRNA expression in developing neurons. Neuron 9:449-463.

Silos-Santiago I, 'Lhang L, Snider WD, Klein R, Barbacid M, Smeyne RJ (1993) Characterization of the dorsal root afferent projection to spinal cord in the trkB "knockout" mouse. Soc Neurosci Abstr 19: 1100.

Silos-Santiago I, Molliver DC, Zhang L, Gerfen RW, Dhar-Karihaloo
M, Smeyne RJ, Barbacid M, Snider WD (1994) Subsets of primary sensory neurons die early in embryonic development in the trkA KO mice. Soc Neurosci Abstr 20:238.

Silverman JD, Kruger L (1990) Selective neuronal glycoconjugate expression in sensory and autonomic ganglia: relation of lectin reactivity to peptide and enzyme markers. J Neurocytol 19:789-801.

Smeyne RJ, Klein R, Schnapp A, Long LK, Bryant S, Lewin A, Lira SA, Barbacid M (1994) Severe sensory neuropathies in mice carrying a disrupted Trk/NGF receptor gene. Nature 368:246-249.

Snider WD (1994) Functions of the neurotrophins during nervous system development: what the knockouts are teaching us. Cell 77:627638.

Verdi JM, Birren SJ, Ibáñez CF, Persson H, Kaplan DR, Benedetti M, Chao MV, Anderson DJ (1994) p75 L.NGFR regulates trk signal transduction and NGF-induced neuronal differentiation in MAH cells. Neuron 12:733-745.

Verge VMK, Richardson PM, Benoit R, Riopelle RJ (1989) Histochemical characterization of sensory neurons with high affinity receptors for nerve growth factor. J Neurocytol 18:583-591.

Verge VMK, Merlio JP, Grondin J, Ernfors P, Persson H, Riopelle RJ, Hökfelt T, Richardson PM (1992) Colocalization of NGF binding sites, trk mRNA, and low-affinity NGF receptor mRNA in primary sensory neurons: response to injury and infusion of NGF. J Neurosci 12:4011-4022.

Willis WD, Coggeshall RE (1991) Sensory mechanisms of the spinal cord, Second Ed. New York: Plenum.

Wright DE, Snider WD (1995) Neurotrophin receptor mRNA expression defines distinct populations of neurons in rat dorsal root ganglia. J Comp Neurol 351:329-338.

Yip HK, Rich, KM, Lampe PA, Johnson EM (1984) The effects of nerve growth factor and its antiserum on the postnatal development and survival after injury of sensory neurons in rat dorsal root ganglia. J Neurosci 4:2986-2992.

Zhang L, Silos-Santiago I, Gerfen RW, Wright DE, Snider WD (1994) Neurotrophin receptors are expressed by DRG neurons during the period of proliferation of neuronal precursors and early axon extension by differentiated neurons. Soc Neurosci Abstr 20:658. 